\title{
CrimRxiv
}

\section{La (ré)intégration sociocommunautaire comme réponse au morcellement organisationnel et clinique des personnes judiciarisées}

Bastien Quirion, Sylvie Hamel, Jocelyn Gadbois, Natacha Brunelle

Published on: Feb 22, 2022

DOI: 10.21428/cb6ab371.c189ele1

License: Creative Commons Attribution 4.0 International License (CC-BY 4.0). 
